\title{
Isolation and characterization of oligomerization domain I and II coding regions of doublesex genes in agricultural fruit flies (Diptera: Tephritidae)
}

\author{
RATTIYA PERMPOON and SUJINDA THANAPHUM*
}

Department of Biotechnology, Faculty of Science, Mahidol University, RamaVI Road, 10400 Bangkok, Thailand

Key words. Doublesex genes, Bactrocera, OD1 and OD2 domains, phylogenetic relationships

\begin{abstract}
Bactrocera fruit flies are ranked among the most destructive pests of the worldwide fruit and vegetable trades. Coding regions of two oligomerization domains within doublesex $(d s x)$ genes were determined in Bactrocera dorsalis (oriental fruit fly) and $B$. correcta (guava fruit fly). Resulting sequences revealed a high degree of similarity at both nucleotide and putative amino acid levels in the genus Bactrocera. Conservation of the DNA-binding DM motif and several known molecular features within the domains suggest a presence of strong purifying selection on the DSX proteins. Topology of the phylogenetic gene trees and deduced amino acid substitution patterns suggest that the coding region sequences of the two domains are diversified in concert parallel with the species differentiation.
\end{abstract}

\section{INTRODUCTION}

Sex determination in Drosophila melanogaster is regulated by the so-called X : A ratio and an RNA-splicing cascade involving sex-specific splicing of sex-lethal (Sxl), transformer (tra), and doublesex ( $d s x$ ) genes (Cline, 1993; Sanchez, 2008). A recent discovery of an important auxiliary role of tra-2 in a tra autoregulatory loop in Ceratitis capitata led to a better understanding of the dipteran sex determination cascade, which could be Y-linked M factor $>\operatorname{tra}>d s x$ (Franz \& Willhof, 1996; Salvemini et al., 2009). Although there might be many different master switches in insects other than Drosophila, their $d s x$ proteins are highly conserved both in structure and function (Saccone et al., 1998, 2002; Shearman, 2002; Oliveira et al., 2009).

In D. melanogaster, the male-specific $\left(\mathrm{DSX}^{\mathrm{M}}\right)$ and femalespecific $\left(\mathrm{DSX}^{\mathrm{F}}\right)$ proteins result from an alternative splicing of the $d s x$ mRNA. Both proteins are active but have an opposing regulatory role in controlling the downstream somatic sexual differentiation genes (Baker \& Wolfner, 1988; Burtis \& Baker, 1989; Cho \& Wensink, 1997). The DSX proteins share a common N-terminal region but differ at a sex-specific C-terminal region. Two functionally important DSX domains are responsible for the protein structure and DNA binding activity (An et al., 1996; Zhu et al., 2000). Oligomerization domain I (OD1) is located within a shared 66-amino-acid segment, common to both male and female isoforms (amino acids 39-104; An et al., 1996). The other important domain consists of both sex-specific and non-sex-specific portions. This domain constitutes a second oligomerization unit: OD2 ${ }^{\mathrm{M}}$ (male-specific; amino acids 350-427) and $\mathrm{OD} 2^{\mathrm{F}}$ (female-specific; amino acids 350-412) (An et al., 1996). These two domains have roles in specific DNA sequence recognition and protein oligomerization. In addition, they can interact with other proteins (Erdman et al., 1996; Cho \& Wensink, 1997; Bayrer et al., 2005; Yang et al., 2008).

Orthologues of the $d s x$ genes have been isolated in nondrosophilid insects such as in Megaselia scalaris (Sievert et al., 1997; Kuhn et al., 2000), Musca domestica (Hediger et al., 2004), Anopheles gambiae (Scali et al., 2005), Bactrocera tryoni (Shearman \& Frommer, 1998), B. oleae (Lagos et al.,
2005), B. dorsalis (Chen et al., 2008), Anastrepha obliqua (Ruiz et al., 2005, 2007), C. capitata (G. Saccone et al., cited in Pane et al., 2002), Bombyx mori (Ohbayashi et al., 2001), Apis mellifera (Cho et al., 2007), and Nasonia wasps (Oliveira et al., 2009). Here, two oligomerization domains in the $d s x$ gene coding regions in both sexes of B. dorsalis and B. correcta (Diptera: Tephritidae) were isolated and characterized.

\section{MATERIAL AND METHODS}

\section{Genomic DNA extraction}

Genomic DNA was extracted from flies obtained from laboratory stocks of B. dorsalis (Hendel) and B. correcta (Bezzi). Individual flies were homogenized in an extraction buffer (100 $\mathrm{mM} \mathrm{NaCl}, 200 \mathrm{mM}$ sucrose, $100 \mathrm{mM}$ Tris-HC1 (pH 9.1), 50 $\mathrm{mM}$ EDTA, $0.5 \%$ SDS, and $100 \mu \mathrm{g} / \mathrm{ml}$ proteinase $\mathrm{K}$ ), treated with RNase A, and purified in phenol : chloroform (Baruffi et al., 1995).

\section{Total RNA extraction}

The total RNA was isolated from adult B. dorsalis and B. correcta flies by using Trizol reagent (Gibco/BRL Life Technologies, Gaithersburg, MD, USA) as recommended by the manufacturer.

\section{Primers}

Primers (Table 1) were designed according to the alignment of the $d s x$ sequences obtained from GenBank: B. tryoni (Froggatt), B. oleae (Gmelin), and Ceratitis capitata (Wiedemann) or otherwise as indicated in Table 1. Refer to supplementary Table S1 for the GenBank accession numbers.

\section{Polymerase chain reaction amplifications}

All amplification reactions were performed in a FlexCycler PCR thermal cycler (Analytik Jena, Germany). Amplification reactions contained $10 \mathrm{ng}$ of genomic DNA, $1 \times$ Taq DNA polymerase buffer A (Vivantis Technologies, Selangor, Malaysia), $200 \mu \mathrm{M}$ of mixed dNTP, $1.5 \mathrm{mM} \mathrm{MgCl}_{2}, 4$ pmol of both $\mathrm{BD}$ and RevBD primers each, and $1 \mathrm{U}$ of Taq DNA polymerase (Vivantis Technologies) in a total volume of $20 \mu \mathrm{l}$. PCR conditions were $94^{\circ} \mathrm{C}$ for $2 \mathrm{~min}$, followed by 35 cycles of $94^{\circ} \mathrm{C}$ for 1

\footnotetext{
* Corresponding author; e-mail: testn@mahidol.ac.th
} 
TABle 1. Primer sequences.

\begin{tabular}{lll}
\hline Primers & Sequence 5' to 3' & References \\
\hline BD & ATGGTTTCTGAGGATAATTGGAACA & Designed in this study \\
RevBD & GGCACTGTGGTCATGTGATG & Designed in this study \\
Btk & CAGCGGCAGTTCGATCTCC & Shearman \& Frommer, 1998 \\
Btl & GCACGGTGCCGTATTCATGG & Shearman \& Frommer, 1998 \\
Oligo $(\mathrm{dT})$ adapter & CGGGACTCGTCGACATCGA(T) $)_{17}$ & Shearman \& Frommer, 1998 \\
Adapter & CGGGACTCGTCGACATCG & Shearman \& Frommer, 1998 \\
\hline
\end{tabular}

min, $60^{\circ} \mathrm{C}$ for $30 \mathrm{~s}, 72^{\circ} \mathrm{C}$ for $1 \mathrm{~min}$; and one cycle of final extension of $72^{\circ} \mathrm{C}$ for $7 \mathrm{~min}$.

\section{3' RACE PCR amplifications}

3' RACE was carried out as described by Frohman et al. (1988). ImProm-II reverse transcription system (Promega, Madison, WI, USA) was used to reverse transcribe $\sim 3-5 \mu \mathrm{g}$ total RNA from adult flies as recommended by the manufacturer. PCR conditions for $3^{\prime}$ RACE were $94^{\circ} \mathrm{C}$ for 4 min, followed by five cycles of $94^{\circ} \mathrm{C}$ for $1 \mathrm{~min}, 60-63^{\circ} \mathrm{C}$ for 2 min and $72^{\circ} \mathrm{C}$ for $2 \mathrm{~min} ; 30$ cycles of $94^{\circ} \mathrm{C}$ for $40 \mathrm{~s}, 58-60^{\circ} \mathrm{C}$ for $2 \mathrm{~min}, 72^{\circ} \mathrm{C}$ for $2 \mathrm{~min}$; and one cycle of final extension of $72^{\circ} \mathrm{C}$ for $7 \mathrm{~min}$. The first amplification reaction employed a BDadapter primer pair while subsequent semi-nested PCRs used Btk and Btl adapter primers.

\section{Fragment isolation, cloning, and sequencing}

PCR products were purified from $1 \%$ agarose gel using the Geneclean II kit (Bio 101 Inc., La Jolla, CA, USA), and then ligated into pGEM-T Easy Vector (Promega). The recombinant plasmids were transformed into $\mathrm{DH} 5 \alpha$ competent cells with blue/white colony screening. Plasmids were isolated as described by Sambrook et al. (1989). All sequencing was performed on both strands using the ABI3730XL sequencer serviced by Macrogen Inc., Seoul, South Korea.

\section{Sequence alignment and phylogenetic tree reconstruction}

ClustalW (1.83) was used to align sequences (Thompson et al., 1994). Programs from the PHYLIP package version 3.68 (Felsenstein, 2004) and TREEVIEW program (Page, 1996) were used to reconstruct the phylogenetic trees. Refer to supplementary Table S1 for the molecular sequences in the alignments.

\section{RESULTS AND DISCUSSION}

The coding regions of Drosophila DSX OD1 orthologues were isolated from the genomic DNA of $B$. dorsalis $\left(\mathrm{Bd}_{1 \mathrm{DSX}}^{\mathrm{M}}\right.$ $\mathrm{OD} 1$ and $\left.\mathrm{Bd} 1 \mathrm{DSX} \mathrm{F}^{\mathrm{F}} \mathrm{OD} 1\right)$ and $B$. correcta $\left(\mathrm{BcDSX} \mathrm{M}^{\mathrm{M}} \mathrm{OD} 1\right.$ and $\left.\mathrm{BcDSX}^{\mathrm{F}} \mathrm{OD} 1\right)$. Since the OD2 coding region of the $d s x$ gene is composed of both sex-specific and non-sex-specific parts (An et al., 1996), the DSX OD2 coding regions of the $d s x$ orthologues were isolated from 3' RACE cDNA fragments of $B$. dorsalis $\left(\mathrm{Bd} 1 \mathrm{DSX} \mathrm{M}^{\mathrm{M}} \mathrm{OD} 2\right.$ and Bd1DSX $\left.\mathrm{F}^{\mathrm{F}} \mathrm{OD}\right)$ and $B$. correcta $\left(\mathrm{BcDSX}^{\mathrm{M}}\right.$ $\mathrm{OD} 2$ and $\left.\mathrm{BcDSX}^{\mathrm{F}} \mathrm{OD} 2\right)$. Longer male cDNA sequences were observed in the DSX OD2 orthologues of both species. This was consistent with previous findings for other Diptera insects such as B. tryoni (Shearman \& Frommer, 1998), B. oleae (Lagos et al., 2005), A. obliqua (Ruiz et al., 2005), and D. melanogaster (Burtis \& Baker, 1989; An et al., 1996). A BLAST search confirmed that these genomic and cDNA fragments were parts of the $d s x$ genes by grouping $B$. dorsalis and $B$. correcta $d s x$ with those of other species. The sequence boundaries corresponding to D. melanogaster DSX OD1 and OD2 were determined in $B$. dorsalis and $B$. correcta by multiple sequence alignments (Figs 1 and 2). The GenBank accession numbers for this work are FJ185162, FJ176944, FJ185165, and FJ185166.

A high degree of sequence conservation was observed in both DSX OD1 and OD2 domains of $B$. dorsalis and $B$. correcta (Table 2). The nucleotide identity of the two domains was the highest in Bactrocera (92-99\%), less in other genera of tephri-

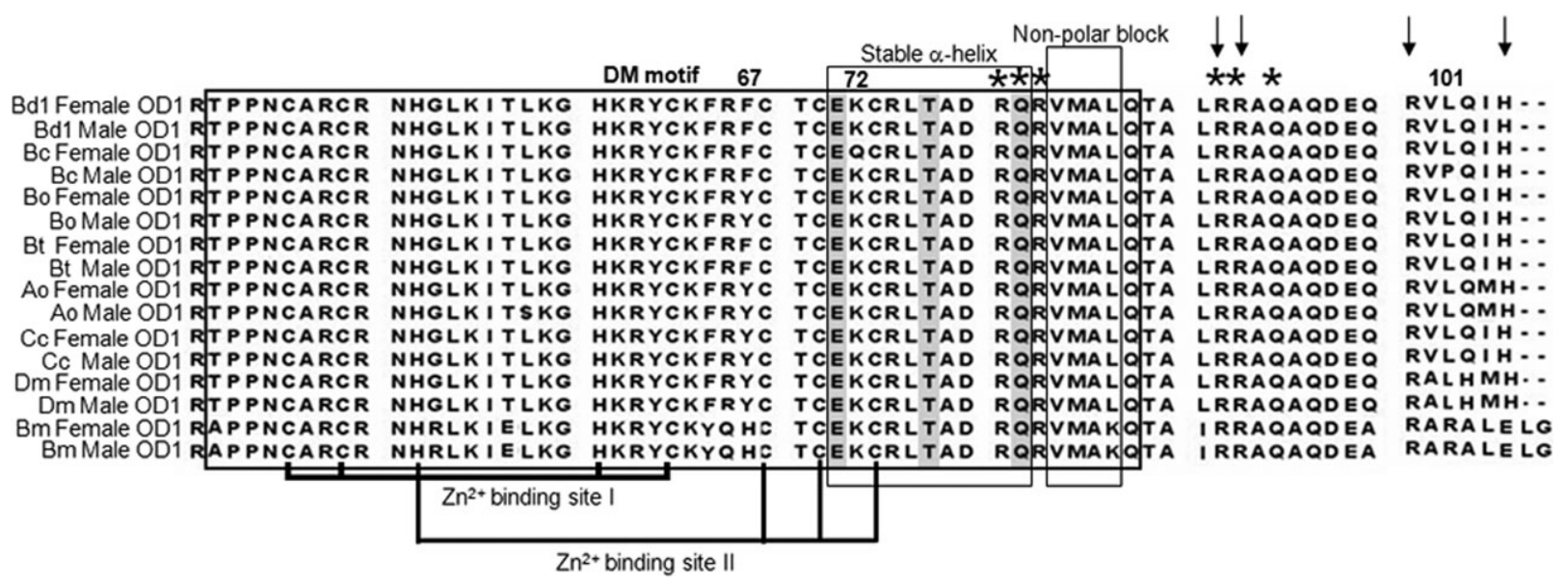

Fig. 1. Aligned putative amino acid sequences of DSX OD1 domain. Regions of DM motif, stable $\alpha$-helix, and a series of nonpolar side chain amino acids are indicated in three blocks. Both $\mathrm{Zn}^{2+}$ ion binding sites, CCHC and HCCC are represented as $\mathrm{Zn}^{2+}$ binding sites I and II, respectively (Zhu et al., 2000). Asterisks (*) indicate two patches of conserved RQ side chains and arrows illustrate basic amino acids at C-terminal distal end (Narendra et al., 2002). Three amino acids conserved within most of the insects (E, T, and Q) are shaded (Oliveira et al., 2009). Putative amino acid changes in B. dorsalis and B. correcta are indicated at positions 67, 72, and 101. Positions of putative amino acid residue correspond to those of D. melanogaster DSX (An et al., 1996). Refer to supplementary Table S1 for the abbreviation for the species and the GenBank accession numbers. 


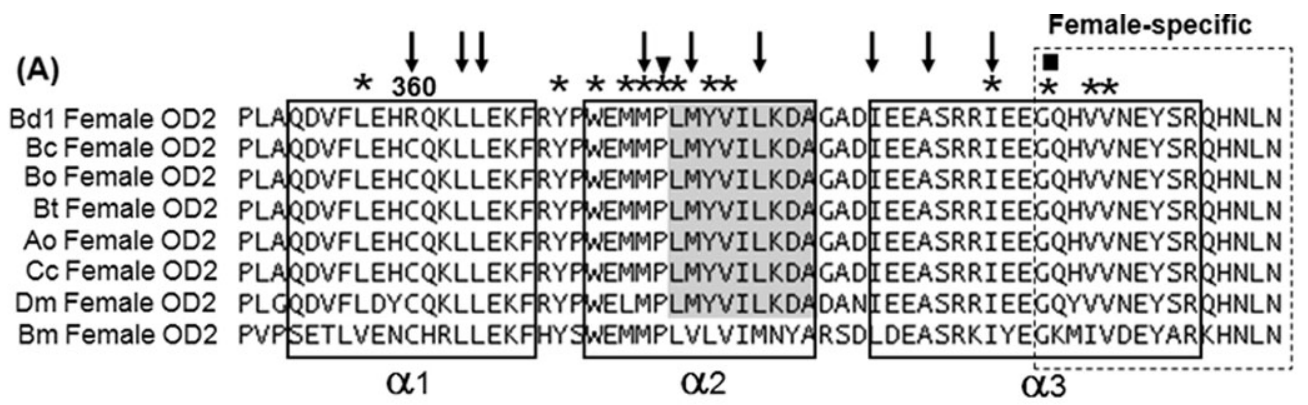

(B)

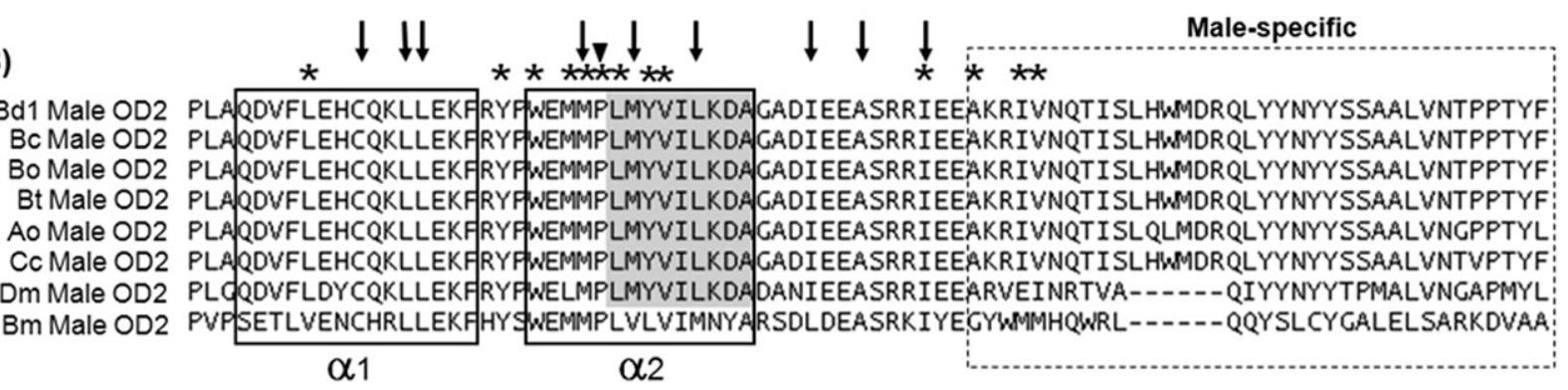

Fig. 2. Aligned putative amino acid sequences of $\mathrm{DSX}^{\mathrm{F}} \mathrm{OD} 2$ domain (A) and $\mathrm{DSX} \mathrm{X}^{\mathrm{M}} \mathrm{OD} 2$ domain (B). The highlighted molecular features of the following are summarized from the indicated references. The regions of $\alpha 1, \alpha 2$, and $\alpha 3$ of the UBA-like folds are indicated in three successive blocks. Dash-lined blocks represent sex-specific portions of the OD2. Asterisks ${ }^{*}$ ) indicate the positions of amino acids in the non-polar core of the dimerization surface and arrows illustrate the positions of a hydrophobic minicore (Bayrer et al., 2005). A triangle ( $\mathbf{v})$ indicates at a proline kink at position 375 and the square (- $\mathbf{(})$ indicates mutation G398D which is associated with an intersexual development (Erdman et al., 1996). There is only one amino acid change, C360R, is observed in $B$. dorsalis $\mathrm{DSX} \mathrm{F}^{\mathrm{F}} \mathrm{OD} 2$ sequence. The amino acid patch (LMYVILKDA), which is mostly conserved in most Diptera, is shaded (Oliveira et al., 2009). Some of the molecular features indicated in the DSX ${ }^{\mathrm{M}}$ OD2 domain were from the study of females (Bayrer et al., 2005). Positions of putative amino acid residue correspond to those of D. melanogaster DSX (An et al., 1996). Refer to supplementary Table S1 for the abbreviation for the species and the GenBank accession numbers.

tids $(81-89 \%)$, and dropped even more so in compared to $D$. melanogaster (45-77\%). A known molecular analysis of the Anastrepha fruit flies indicated that a strong purifying selection acting on the $d s x$ gene has led to the preservation of the functional structure of the DSX proteins (Ruiz et al., 2007). However, our results revealed a substantial difference at the nucleotide level even between fruit flies in the same family.

The topology of the phylogenetic trees (Fig. 3A and B) indicated that all Bactrocera fruit flies are in one clade. The bootstrap values that isolated the fruit flies into the following clades: genus of Bactrocera, other genera of the Tephritidae (A. obliqua and $C$. capitata), and those of more distantly-related insect species (D. melanogaster and B. mori) were very high. The specific clustering and phylogenetic relationships of the two DSX domains were congruent with the taxonomic classification. Thus, it can be inferred that the diversification of the coding regions of DSX OD1 and OD2 domains has changed in parallel concert with the differentiation of the species.

Based on the amino acid similarity between more distantlyrelated species and the tephritid consensus, the DSX OD1 domain seems to have relatively higher similarity $(95.59 \% D$. melanogaster and $76.47 \%$ B. mori) than that of the OD2 $(87.5 \%$ D. melanogaster versus $52.08 \%$ B. mori). A DM motif, which is found in the sex-determination pathway of organisms across the phyla, was also uncovered in the DSX OD1 region (Raymond et al., 1998). All the Dipterans included in this study have identical zinc modules, a stable $\alpha$-helix region, and a non-polar block (VMAL) within the DM motif (Zhu et al., 2000; Narendra et al., 2002). The three highly conserved amino acids (E, T, and Q) shared among $d s x$ from a broad spectrum of insect taxa are also present in residues 71-80 of the stable $\alpha$-helix (Fig. 1) (Zhu et al., 2000; Oliveira et al., 2009). Based on the ability of D. melanogaster $\mathrm{DSX}^{\mathrm{M}}$ to restore a male-specific feature in Caenorhabditis elegans (Raymond et al., 1998) and the analyzed amino acid conservation, it can be inferred that the DSX OD1 is more conserved than the OD2.

The conservation of certain amino acid was detected in the common region of DSX OD2. Fig. 2A and B showed a nine amino acid stretch (LMYVILKDA) and the three $\alpha$-helices that make up the UBA-like fold in $B$. dorsalis and $B$. correcta. These

TABLE 2. Nucleotide and putative amino acid similarity indicated by the multiple alignment analysis.

\begin{tabular}{|c|c|c|c|c|c|c|}
\hline \multirow[t]{2}{*}{$\begin{array}{l}\text { Regions of } B . \text { dorsalis } \\
\text { and } B . \text { correcta } d s x \text { genes }\end{array}$} & \multicolumn{2}{|c|}{ In the genus Bactrocera } & \multicolumn{2}{|c|}{$\begin{array}{c}\text { Among different genera } \\
\text { of Tephritidae }\end{array}$} & \multicolumn{2}{|c|}{$\begin{array}{l}\text { Among different families } \\
\text { of Diptera }\end{array}$} \\
\hline & $\begin{array}{c}\text { Nucleotide } \\
\text { level }\end{array}$ & $\begin{array}{c}\text { Amino acid } \\
\text { level }\end{array}$ & $\begin{array}{c}\text { Nucleotide } \\
\text { level }\end{array}$ & $\begin{array}{c}\text { Amino acid } \\
\text { level }\end{array}$ & $\begin{array}{c}\text { Nucleotide } \\
\text { level }\end{array}$ & $\begin{array}{c}\text { Amino acid } \\
\text { level }\end{array}$ \\
\hline DSX OD1(common to both sexes) & $92-96 \%$ & $96-100 \%$ & $81-83 \%$ & $93-98 \%$ & $75-76 \%$ & $92-93 \%$ \\
\hline DSX $^{\mathrm{M}}$ OD2 (252 bp) & $97-99 \%$ & $100 \%$ & $86-88 \%$ & $95-98 \%$ & $45-47 \%$ & $73 \%$ \\
\hline DSX $^{\mathrm{F}}$ OD2 (189 bp) & $97-98 \%$ & $98-100 \%$ & $86-89 \%$ & $98-100 \%$ & $76-77 \%$ & $87-88 \%$ \\
\hline
\end{tabular}


(A)

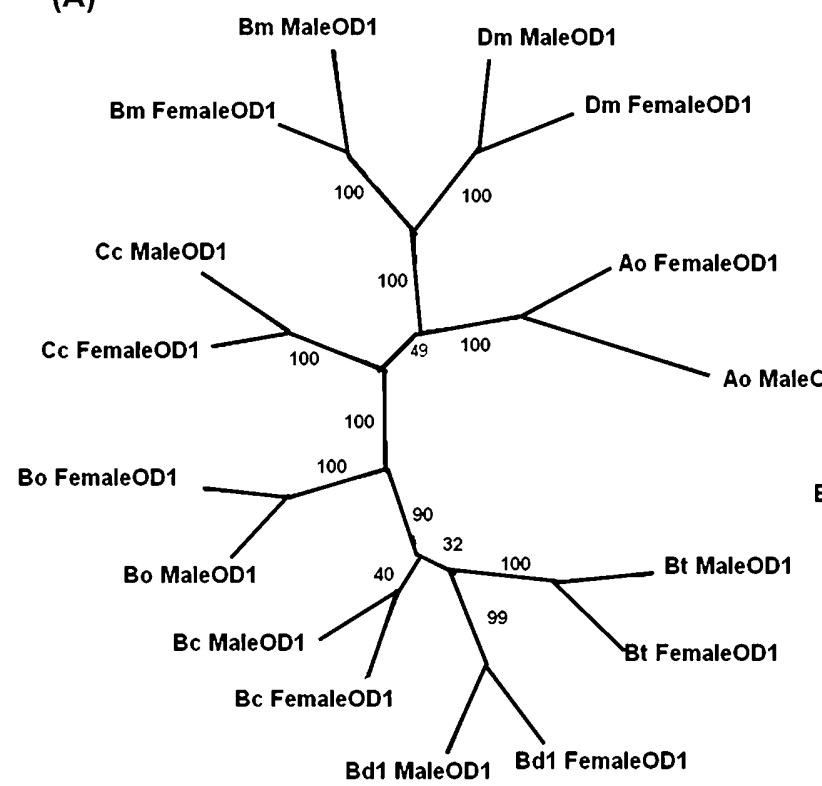

(B)

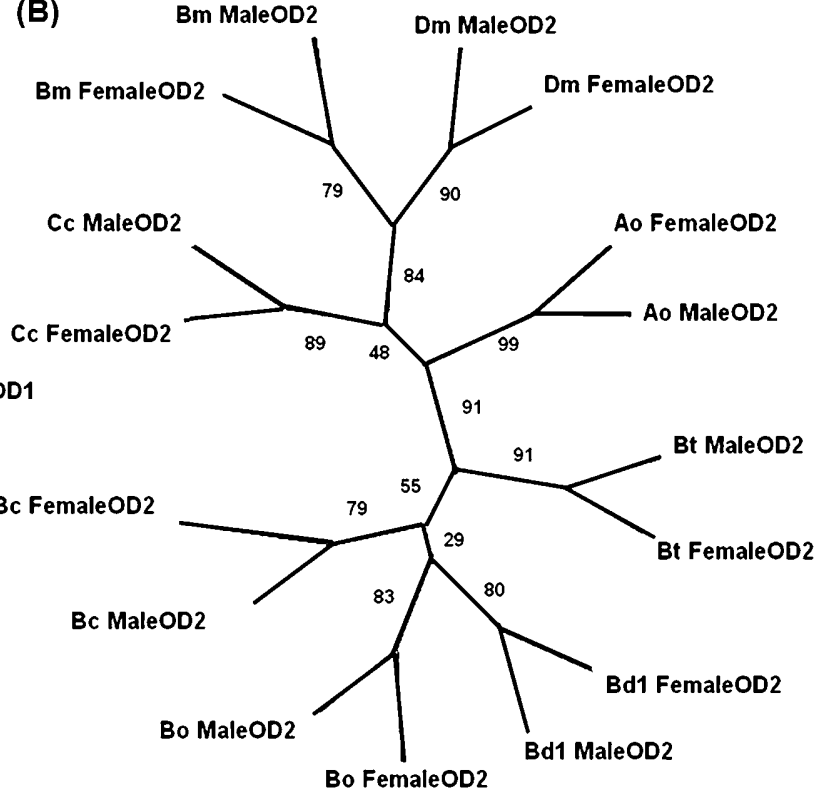

Fig. 3. A 50\% majority-rule consensus UPGMA phylogenetic tree based on both male and female sorted nucleotide sequence variable sites of DSX OD1 (A) and the common region of DSX OD2 (B) coding region sequences. The bootstrap values (100 replicates) are indicated on each node. Genetic distances of individual branches are not indicated. Refer to supplementary Table S1 for the abbreviation for the species and the GenBank accession numbers.

molecular features suggest the presence of a ubiquitin regulatory component. (Bayrer et al., 2005; Yang et al., 2008; Oliveira et al., 2009).

Despite the conservation of the DSX proteins in different species, these proteins cannot act as substitute for one another. Examples are the ectopic expressions of $M$. domestica (Hediger et al., 2004), C. capitata (Saccone et al., 2008), and A. obliqua (Alvarez et al., 2009) DSX proteins in D. melanogaster. This might be due to the accumulation of minor differences between these species. All three alterations, Y67F, K72Q, and L101P in the DSX OD1 (Fig. 1) are located within the identified zinc module and the disordered C-terminal tail important for DNA recognition and affinity (Erdman \& Burtis, 1993; Zhu et al., 2000). An amino acid substitution at Y67F was found in both sexes of B. dorsalis, B. correcta, and B. tryoni. This amino acid change was identified as being tolerant of amino acid substitutions (Zhang et al., 2006). Likewise, the amino acid changes at both positions 72 and 101 in OD1 can be different in males and females of $B$. correcta, because they might be selectively neutral polymorphisms. $\mathrm{L}$ and $\mathrm{P}$ amino acid residues at position 101 are both nonpolar in the C-terminal tail of OD1. The basic polar nature of $\mathrm{K}$ and polar nature of $\mathrm{Q}$ may be selectively neutral, because position 72 is closely flanked by two more important cysteine residues of the $\mathrm{Zn}^{2+}$ binding site II. In addition, there is an amino acid substitution, C360R, in Bd1DSX ${ }^{\mathrm{F}}$ OD2. Bayrer et al. (2005) studied a crystal structure of the $\mathrm{CTD}^{\mathrm{F}}$ and it was revealed that the side chain of $\mathrm{C} 360$ is one of the centers for a hydrophobic minicore. However, whether the positively charged side chain of C360R has any effects on the oligomerization of the DSX protein or not needs to be biochemically determined.

This work on the sequencing and phylogenetic analysis of two important domains of the doublesex genes in two different Bactrocera species suggests that one objective of future studies on sex determination should be to develop their original genetic tools such as RNAi, promoter, DNA primers, and a probe system from genes such as $d s x$, tra, and tra-2. This might lead to the development of genetic sexing strains which could result in more effective programs for controlling species of Bactrocera, using sterile insect technique (SIT) (Handler, 2002).

ACKNOWLEDGEMENTS. This research was supported by research contract no. 12620 of the International Atomic Energy Agency, Vienna, Austria, to S. Thanaphum. This study is also a part of the master degree of R. Permpoon under the supervision by $\mathrm{S}$. Thanaphum at Mahidol University.

\section{REFERENCES}

Alvarez M., Ruiz M.F. \& Sanchez L. 2009: Effect of the gene doublesex of Anastrepha on the somatic sexual development of Drosophila. PLoS ONE 4: e5451.

An W., Cho S., Ishi H. \& Wensink P.C. 1996: Sex-specific and non-sex-specific oligomerization domains in both of the doublesex transcription factors from Drosophila melanogaster. Mol. Cell. Biol. 16: 3106-3111.

BAKER S.B. \& WolfNer M.F. 1988: A molecular analysis of doublesex, a bifunctional gene that controls both male and fenale sexual differentiation in Drosophila melanogaster. Genes Dev. 2: 477-489.

Baruffi L., Damiani G., Guglielmino C.R., Bandi C., MalacRIDA A.R. \& GASPeri G. 1995: Polymorphism within and between populations of Ceratitis capitata: comparison between RAPD and multilocus enzyme electrophoresis data. Heredity 74: 425-437.

BAYRER J.R., ZHANG W. \& WeISS M.A. 2005: Dimerization of doublesex is mediated by a cryptic UBA-domain fold: Implication for sex-specific gene regulation. J. Biol. Chem. 280: 32989-32996.

Burtis K.C. \& BAKer B.S. 1989: Drosophila doublesex gene controls somatic sexual differentiation by producing alternatively spliced mRNAs encoding related sex-specific polypeptides. Cell 56: 997-1010.

Chen S.L., Dai S.M., Lu K.H. \& Chang C. 2008: Femalespecific doublesex dsRNA interrupts yolk protein gene expression and reproductive ability in oriental fruit fly, Bac- 
trocera dorsalis (Hendel). Insect Biochem. Mol. Biol. 38: $155-165$.

Chо S. \& Wensink P.C. 1997: DNA binding by the male and female doublesex proteins of Drosophila melanogaster. $J$. Biol. Chem. 272: 3185-3189.

Cho S., Huang Z.Y. \& Zhang J. 2007: Sex-specific splicing of the honeybee doublesex gene reveals 300 million years of evolution at the bottom of the insect sex-determination pathway. Genetics 177: 1733-1741.

Cline T.W. 1993: The Drosophila sex determination signal: How do flies count to two? Trends Genet. 9: 386-390.

ERdman S.E. \& Burtis K.C. 1993: The Drosophila doublesex proteins share a novel zinc finger related DNA binding domain. EMBO 12: 527-535.

Erdman S.E., Chen H.J. \& Burtis K.C. 1996: Functional and genetic characterization of the oligomerization and DNA binding properties of the Drosophila doublesex proteins. Genetics 144: 1639-1652.

Felsenstein J. 2004: PHYLIP (Phylogeny Inference Package), Version 3.68. Distributed by the author. Department of Genome Sciences, University of Washington, Seattle.

Franz G. \& WillhoF U. 1996: Identification of the sexdetermining region of the Ceratita capitata $\mathrm{Y}$ chromosome by deletion mapping. Genetics 144: 737-745.

Frohman M.A., Dush M.K. \& Martin G.R. 1988: Rapid production of full-length cDNAs from rare transcripts: Amplifications using a single gene-specific oligonucleotide primer. Proc. Natl. Acad. Sci. USA 85: 8998-9002.

HANDLER A.M. 2002: Prospects for using genetic transformation for improved SIT and new biocontrol methods. Genetica 116: 137-149.

Hediger M., Burghardt G., Siegenthaler C., Buser N., Hilfiker-Kleiner D., Dubendorfer A. \& Bopp D. 2004: Sex determination in Drosophila melanogaster and Musca domestica converges as the level of the terminal regulator doublesex. Dev. Genes Evol. 214: 29-42.

Kuhn S., Sievert V. \& Traut W. 2000: The sex-determining gene doublesex in the fly Megaselia scalaris: conserved structure and sex-specific splicing. Genome 43: 1011-1020.

Lagos D., Ruiz M.F. \& SANChez L. 2005: Isolation and characterization of the Bactrocera oleae genes orthologous to the sex determination sex-lethal and doublesex genes of Drosophila melanogaster. Gene 348: 111-121.

Narendra U., Zhu L., Li B., Wilken J. \& Weiss M.A. 2002: Sex-specific gene regulation: The doublesex DM motif is a bipartite DNA-binding domain. J. Biol. Chem. 277: 43463-43473.

Ohbayashi F., Suzuki M.G., Mita K. \& Okano K. 2001: A homologue of the Drosophila doublesex gene is transcribed into sex-specific mRNA isoforms in the silkworm, Bombyx mori. Comp. Biochem. Physiol. (B) 128: 145-158

Oliveira D.C.S.G., Werren J.H., Verhulst E.C., Giebel J.D., Kamping A., Beukeboom L.W. \& Van de Zande L. 2009: Identification and characterization of the doublesex gene of Nasonia. Insect Mol. Biol. 18: 315-324.

PAGE R.D.M. 1996: TREEVIEW: An application to display phylogenetic trees on personal computers. CABIOS 12: 357-358.

Pane A., Salvemini M., Delli B.P., Polito C. \& Saccone G. 2002: The transformer gene in Ceratitis capitata provides a genetic basis for selecting and remembering the sexual fate. Development 129: 3715-3725.

Raymond C.S., Shamu C.E., Shen M.M., Seifert K.J., Hirsch B., Hodgkin J. \& Zarkower D. 1998: Evidence for evolu- tionary conservation of sex-determining genes. Nature 391: 691-695.

Ruiz M.F., Stefani R.N., Mascarenhas R.O., Perondini A.L.P., Selivon D. \& SAnchez L. 2005: The Gene doublesex of the fruit fly Anastrepha obliqua (Diptera, Tephritidae). Genetics 171: 849-854.

Ruiz M.F., Eirin-Lopez J.M., Stefani R.N., Perondini A.L.P., Selivon D. \& Sanchez L. 2007: The gene doublesex of Anastrepha fruit flies (Diptera, Tephritidae) and its evolution in insects. Dev. Genes Evol. 217: 725-731.

Saccone G., Peluso I., Astiaco D., Giordano E., Bopp D. \& Polito L.C. 1998: The Ceratitis capitata homologue of the Drosophila sex-determining gene Sex-lethal is structurally conserved, but not sex-specifically regulated. Development 125: $1495-1500$.

Saccone G., Pane A. \& Polito L.C. 2002: Sex determination in flies, fruitflies and butterflies. Genetica 116: 15-23.

Saccone G., Salvemini M., Pane A. \& Polito L.C. 2008: Masculinization of XX Drosophila transgenic flies expressing the Ceratitis capitata DoublesexM isoform. Int. J. Dev. Biol. 52: $1043-1050$

Salvemini M., Robertson M., Aronson B., Atkinson P., Polito L.C. \& SACCone G. 2009: Ceratitis capitata transformer-2 gene is required to establish and maintain the autoregulation of Cctra, the master gene for female sex determination. Int. J. Dev. Biol. 53: 109-120.

Sambrook K.J., Fritsch E.F. \& Maniatis T. 1989: Molecular Cloning: A Laboratory Manual. 2nd ed. Cold Spring Harbor Laboratory Press, New York, 1590 pp.

SANCHEZ L. 2008: Sex-determining mechanisms in insects. Int. J. Dev. Biol. 52: 837-856.

Scali C., Catteruccia F., Li Q. \& Crisanti A. 2005: Identification of sex specific transcripts of the Anopheles gambiae doublesex gene. J. Exp. Biol. 208: 3701-3709.

SHEARMAN D.C.A. 2002: The evolution of sex determination system in dipteran insects other than Drosophila. Genetica 116: $25-43$.

SheArman D.C.A. \& Frommer M. 1998: The Bactrocera tryoni homologue of the Drosophila melanogaster sex-determination gene doublesex. Insect Mol. Biol. 7: 355-366.

Sievert V., Kuhn S. \& Traut W. 1997: Expression of the sex determination cascade genes Sex-lethal and doublesex in the phorid fly Megaselia scalaris. Genome 40: 211-214.

Thompson J.D., Higgins D.G. \& Gibson T.J. 1994: CLUSTAL W: Improving the sensitivity of progressive multiple sequence alignment through sequence weighting, position-specific gap penalties and weight matrix choice. Nucl. Acids Res. 22: 4673-4680.

Yang Y., Zhang W., Bayrer J.R. \& Weiss M.A. 2008: Doublesex and the regulation of sexual dimorphism in Drosophila melanogaster: Structure, function, and mutagenesis of a female-specific domain. J. Biol. Chem. 283: 7280-7292.

Zhang W., Li B., Singh R., Narendra U., Zhu L. \& Weiss M.A. 2006: Regulation of sexual dimorphism: Mutational and chemogenetic analysis of the doublesex DM domain. Mol. Cell. Biol. 26: 535-547.

Zhu L., Wilken J., Phillips N.B., Narendra U., Chan G., Stratton S.M., Kent S.B. \& Weiss M.A. 2000: Sexual dimorphism in diverse metazoans is regulated by a novel class of intertwined zinc fingers. Genes Dev. 14: 1750-1764.

Received August 31, 2009; revised and accepted September 25, 2009 
TABLE S1. The molecular sequences used in the alignments and their GenBank accession numbers.

\begin{tabular}{|c|c|c|}
\hline Name of the domain & Species & GenBank accession numbers \\
\hline Bd1 DSX OD1 or OD2 & B. dorsalis (this work) & $\begin{array}{l}B d 1 d s x^{m}: \text { FJ185162 } \\
B d 1 d s x^{f}: \text { FJ176944 }\end{array}$ \\
\hline Bc DSX OD1 or OD2 & B. correcta (this work) & $\begin{array}{l}B c d s x^{m}: \text { FJ185165 } \\
B c d s x^{f}: \text { FJ185166 }\end{array}$ \\
\hline Bo DSX OD1 or OD2 & B. oleae & $\begin{array}{l}\text { Bodsx } x^{m}: \text { AJ547622 } \\
\text { Bodsx }: \text { AJ547621 }\end{array}$ \\
\hline Bt DSX OD1 or OD2 & B. tryoni & $\begin{array}{l}\text { Btdsx } x^{m}: \text { AF029676 } \\
\text { Btdsx }: \text { AF029675 }\end{array}$ \\
\hline Ao DSX OD1 or OD2 & A. obliqua & $\begin{array}{l}\text { Aodsx }{ }^{m}: \text { AY948421 } \\
\text { Aodsx }: \text { AY948420 }\end{array}$ \\
\hline Cc DSX OD1 or OD2 & C. capitata & $\begin{array}{l}C c d s x^{m}: \mathrm{AF} 434935 \\
C c d s x^{f:} \mathrm{AF} 435087\end{array}$ \\
\hline Dm DSX OD1 or OD2 & D. melanogaster & Dmdsx: AE014279 \\
\hline Bm DSX OD1 or OD2 & B. mori & $\begin{array}{l}B m d s x^{m}: \mathrm{AB} 048544 \\
B m d s x^{f}: \mathrm{AB} 048543\end{array}$ \\
\hline
\end{tabular}

